\title{
Where did the sessions of the Vilnius sejmik take place in 1717-1795?
}

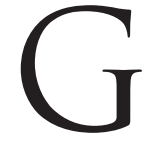

eneral assemblies of the nobility, sejmiks in particular, were important events in the life of the city. Having arrived at the sejmik session, the nobility not only adopted new resolutions or elected local functionaries and representatives of various state institutions, but also, in their free time, came into contact with people of different social strata. The cities were coming alive, just as during the fairs. And on the political "market", the arriving noblemen enjoyed themselves and had a fun time. In the mid- $18^{\text {th }}$ century, an anonymous author associated with Potocki aptly described the social context of sejmiks, though slightly exaggerating: "Sejmiks were held all over the city. Each church, each street, each house and finally, each inn, basement or pit made for a decent setting..."

It should be noted that the well-known law on cities of April 18, $1791^{2}$, also mentions that, to a greater or lesser extent, sejmiks contributed to the strengthening of cities and county centers in the province. Such a tendency can be observed in the Grand Duchy of Lithuania (further on: GDL) after the administrative reform in 1791 as splitting counties into smaller units increased the number of towns in which sejmiks were held.

* The Faculty of Education in Humanities, The Department of Lithuanian History / Wydział Humanistyczny, Katedra Historii Litwy, e-mail: robertas.jurga itis@1eu.1t.

1 A discussion on sejmiks, The Central Archives of Historical Records in Warsaw [further on: AGAD], The Public Archives of Potocki's Family No. 252, p. 34.

${ }^{2}$ Volumina legum [further on: VL], vol. IX, Kraków 1889, pp. 215-216. 
Although the discussions on the locations of sejmik sittings in the counties of GDL already appear in the literature ${ }^{3}$, detailed studies on particular sejmiks reveal additional facts. In the historiography of recent years, the attention is drawn to the location of the Vilnius sejmik sessions in GDL ${ }^{4}$. In the article, I would like to look into this subject matter in relation to the years 1717-1795. It should not be forgotten that until 1777, the sejmiks-in-exile of the Smolensk voivodship were held in Vilnius.

\section{In loco solito}

While in the second half of the $16^{\text {th }}$ century and in the $17^{\text {th }}$ century, due to various disturbances, the Vilnius sejmik was sometimes taking place neither in Vilnius itself nor in the Vilnius county ${ }^{5}$, in the $18^{\text {th }}$ century the assembly of nobility was consistently held in the capital of GDL ${ }^{6}$. A permanent location of sejmiks, most commonly corresponding to the county and voivodships centers, was established in the laws treating on the activity of sejmiks in GDL at the end of $18^{\text {th }}$ century ${ }^{7}$. It is rather complicated to determine

${ }^{3}$ A.B. Zakrzewski, Sejmiki Wielkiego Księstwa Litewskiego XVI-XVIII $w$. Ustrój i funkcjonowanie: sejmik trocki, Warszawa 2000, pp. 29-34; A. Rachuba, Wielkie Księstwo Litewskie w systemie parlamentarnym Rzeczypospolitej w latach 1569-1763, Warszawa 2002, pp. 81-90, p. 200; id e m, Miejsca obrad sejmików Wielkiego Ksiestwa Litewskiego w latach 1569-1794, [in:] Parlamenckije struktury ulady u sistemie dzerzavnaga kiravanie Velikaga Kniastva Litouskaga, Minsk 2008, pp. 183-197.

${ }^{4}$ A. Ragauskas, Viešasis gyvenimas Vilniaus Žemutinès pilies teritorijoje XVI-II a., [in:] Vilniaus Žemutiné pilis XIV a. - XIX a. pradžioje: 2005-2006 m. tyrimai, sudarè L. Glemža, Vilnius 2007, pp. 103-104; R. Jurgaitis, Bajoriškas seimelis mieste: kur vykdavo Vilniaus seimelio posédžiai 1717-1795 m.?, [in:] Lietuvos Didžioji Kunigaikštystè XVIII amžiuje: miesto erdvé, Vilnius 2007, pp. 45-53.

5 The non-standard places of the Vilnius sejmik appear in the historiography: Valkininkai (1572), Niemieża (1625), Radashkovichy (1626), Medininkai (1654) and Kamieniec Litewski (1659). See J. Se redyka, Instrukcje powiatu wileńskiego na sejmy za panowania Zygmunta III Wazy, "Śląski Kwartalnik Historyczny Sobótka” 1993, vol. XLVIII, No. 2-3, p. 191; A. Rachuba, op. cit., p. 82, 84.

6 "Each county holds the sejmik sessions in their own town where they select two deputies to the Diet...”. See Wilenskie Woiewodztwo, Kalendarz polityczny na Rok P. 1747, Lublin [1746].

${ }^{7}$ In the statutes of the sejmiks of 1791 and 1793, the first paragraph of the $1^{\text {st }}$ chapter treats on the place where the sejmiks met: "One city per each sejmik, and in the city one place to assemble we appoint once and for all". See Sejmiki, VL, vol. IX, p. 233. "One city per each sejmik, and in the city one place to assemble is set once and for all”. See Sejmiki W. Ks. Litewskiego, VL, vol. X, Poznań 1952, p. 127. 
a particular locale (building, room) of the sessions. Without doubt, it must have been changing over such a long period of 1717-1795.

First of all, the sources do not include any clear and comprehensive information on the matter. Given that the location was obvious to the participants, it comes as no surprise that the location was not indicated. Therefore, most frequently the documents of the sejmik simply state that the gathering was "in the city of Vilnius, the castle of His Majesty" or "in the Vilnius castle". Sometimes it was added: "in the usual place" (ad solitum locum) ${ }^{9}$. Putting emphasis on the constancy of the meeting place may have a formal tone: the factor of a regular location gained significance when the sejmiks were split, as the one held in a non-regular place might have been considered unlawful. The importance of this issue is illustrated by the debate between the participants of the pre-convocation sejmik session about the place of the meeting on February 6, 1764. The supporters of Ignacy Pac, the steward of GDL, waited until 3 PM until the session of the proponents of Ignacy Jakub Massalski, the Bishop of Vilnius, finished. It was not until then that they started the meeting ${ }^{10}$. Pac's supporters managed to accept the documents of the sejmik and include them in the records of the municipal court already on February $7^{11}$, whereas Massalski's proponents on

8 "...they arrived at the pre-convocation sejmik in the city of HM at the regular place of meeting in the Vilnius Castle...". See The resolutions of the Vilnius sejmik of March 20, 1733, The Lithuanian State Historical Archives in Vilnius [further on: LVIA], f. 21 , op. 1 , No. 91, p. 164.

9 "...the nobility of the voivodship arrived in big numbers in solito loco in the Castle...". See $Z$ Wilna d. 14. Febr., "Kuryer Polski", February 14, 1740, No. 163. "...arriving at the Castle ad solitum locum of the sejmik...". See $Z$ Wilna d. 10. Febr., "Kuryer Polski”, February 10, 1742, No. 272. “...in solito consiliorum loco...". See The instructions of the Vilnius sejmik of August 1748, LVIA, f. 21, op. 1, No. 103, p. 954v. "having gathered in the city and in the Castle of HM in Vilnius, ad solitum consiliorum locum...". See The authorization of the Vilnius sejmik of February 7, 1770 , LVIA, f. 21 , op. 1, No. 128, p. 18. "gathering in Vilnius, the city of HM, at the location of Candlemas sejmik sitting...". See The authorization of the Vilnius sejmik of February 4, 1782, LVIA, f. 21, op. 1, No. 139, p. 1.

10 Michał Horain's letter of February 13, 1764, The manuscript catalogue of the Vrublevskiai Library of the Lithuanian Academy of Sciences in Vilnus, f. 139, No. 1197, pp. 5-8; W. Kri g g e is e n, Sejmiki Rzeczypospolitej szlacheckiej w XVII i XVIII wieku, Warszawa 1991, p. 98; T. Szwaciński, Sejmiki poselskie przed konwokacja 1764 r., "Kwartalnik Historyczny" 2006, vol. CXIII, No. 1, p. 26.

11 The resolutions of the Vilnius sejmik of February 7, 1764, LVIA, f. 21, op. 1, No. 121, pp. 380-383v; The instructions of the Vilnius sejmik of February 7, 1764, ibidem, pp. 384-387v. 
February $9^{12}$. After the debates were moved to the Warsaw Convocation Sejm and after deputies' powers went under control, the sejmik of Biszop Massalski was recognized as a lawful one and elected the deputies ${ }^{13}$. However, the research carried out in recent years shows that the territory of the Vilnius castles on which most buildings of the GDL institutions were located was large enough to hold their own sejmik assemblies.

The records of the Vilnius municipal court from the $18^{\text {th }}$ century point out that the Vilnius sejmik was meeting in the building of said court, in its meeting room ${ }^{14}$. As stated in the entry of 1715 , the Vilnius municipal court and the sejmik sittings took place in the Castle Gate building ${ }^{15}$. In the descriptions of the Vilnius estates from 1790, it is indicated that court proceedings were held in the Castle Gate building (property No. 462) ${ }^{16}$. In 1794, the tribunal (deputational) and electoral sejmik of Vilnius also met in the room of the Vilnius municipal court ${ }^{17}$. Some of the court records from $18^{\text {th }}$ century also include indirect evidence on the location of the

12 The instructions of the Vilnius sejmik of February 9, 1764, Akty izdavaiemyje Vilenskoju archeograficzeskoju komisieju dla razbora drieunich aktov, vol. XIII, pp. 224-236; The resolutions of the Vilnius sejmik of February 6, 1764, ibidem, pp. 217-221.

${ }^{13}$ Dyaryusz Seymu convocationis Siedmio-Niedzielnego Warszawskiego zdania, Mowy, Projekta y Manifesta $w$ sobie zawieraiacy, przez Sesye zebrany R.P. $1764 w$ Warszawie, [1764], (May 7, 1764, $1^{\text {st }}$ session).

14 "at the door of the castle chamber where the sejmiks are taking place and various courts begin their proceedings..." See LVIA, f. 21, op. 1, No. 67, p. 1393. "... at the door of the chamber of the Vilnius castle, when the sejmiks are taking place and various courts exercise their jurisdiction..." See LVIA, f. 21, op. 1, No. 70, p. 7. "... at the door of the chamber of the Vilnius castle, when the sejmiks are taking place and various courts exercise their jurisdiction..." See LVIA, f. 21, op. 1, No. 70, p. 397. "...at the castle gate, where sejmiks are taking place and various courts exercise their jurisdiction..." See LVIA, f. 21, op. 1, No. 71, p. 956, 1199.

15 "...at the door of the chamber of the Vilnius castle, when the sejmiks are taking place and various courts exercise their jurisdiction..." LVIA, f. 21, op. 1, No. 70 , p. $153 \mathrm{v}$.

16 "...the gate of the Castle where courts function..." See A description of 1790 of the Vilnius city's estate, LVIA, f. 458, op. 1, No. 317 , pp. $15 \mathrm{v}-16$.

17 "...for gathering in the place of sejmik sessions in the Castle of HM in the Vilnius city and in the castle chamber of regular meetings..." See The diary of the Vilnius tribunal sejmik of February 3-7, 1794, LVIA, f. 20, op. 1, No. 39, p. 176. "...to the chamber of the Castle..." See $Z$ Wilna dnia 7 Maja, "Gazeta Narodowa Wileńska", May 7, 1794, No. 2. 
Vilnius sejmik. In 1792, the border court of the Vilnius voivodship held the session in the same place as the sejmik ${ }^{18}$. It can be, therefore, concluded that the Vilnius sejmik gathered in the same place as the municipal court, the land court as well as other courts of the county, while the Castle Gate can be considered a traditional location of the sejmik meetings.

Quite frequently, the sources mention a debating chamber of the sejmik or name a specific room. In his diary, Michał Kazimierz Radziwiłł, also known as Rybeńko, remarks that on October 23-27, 1747, the Vilnius electoral sejmik took place in the sejmik meeting room ("the sejmik chamber") ${ }^{19}$. In the same place (though only at the beginning), the sejmik held its proceedings on February 4-7, $1771^{20}$. Analogous descriptions appear repeatedly. One may gain an impression that the debating chamber of the sejmik was, in fact, the courtroom of the Vilnius voivodship court ${ }^{21}$. Clearly, the sessions of these two institutions might have coincided at times and hence, the sejmik had to look for another place to meet in. On the morning of August 20, 1748, the Vilnius voivode M.K. Radziwiłl, alias Rybeńko, ordered to break an ongoing session of the Vilnius municipal court, postponing it to the later date, and went to the meeting of the Vilnius pre-Sejm sejmik, where he managed to hear the reading of instructions and sign them ${ }^{22}$. In such cases, when the sessions of the sejmik were coinciding with the proceeding of the municipal or land court, the Vilnius sejmik was most probably held elsewhere - in the Palace of the Supreme Tribunal of GDL.

18 "...in Vilnius, the city of sejmik meetings..." See The protocol of the border court of the Vilnius voivodship of 1792 , LVIA, f. 20, op. 1, No. 187, p. 1.

19 Diary of Michał Kazimierz Radziwiłł, alias Rybeńko, AGAD, The Archives of the Radziwiłł Family [further on: AR], sec. VI, II-80a, pp. 1537-1540. “...in the Castle of HM in Vilnius in the sejmik Chamber..." See The manifesto of the nobility of the Vilnius voivodship of August 25, 1760, LVIA, f. 21, op. 1, No. 117, pp. $577-577 \mathrm{v}$.

${ }^{20}$ A description of the Vilnius sejmik of 1771, AGAD, The Popiele Collection [further on: ZP] 722, pp. 466-467v.

${ }^{21}$ In the instructions of the 1718 Vilnius sejmik, treating on the need to renovate the castle, the information about the room of sejmik and court proceedings is indicated ("the sejmik and court chamber"). See The instructions of the Vilnius sejmik of August 22, 1718, AGAD, The Archives of the Zamoyski Family [further on: AZ] 3055, p. 193v.

22 "...I ordered to cancel the court meeting, they went to the sejmik, sat in accordance with their rank, read the instruction and signed it...”. Diary of Michal Kazimierz Radziwiłł, alias Rybeńko, AGAD, AR, II-80a, pp. 1594-1600. 
It was the second meeting place of the Vilnius sejmik. In 1740, the pre-Sejm sejmik gathered in the courtroom ("in the Court Chamber") ${ }^{23}$. Describing the Vilnius pre-Sejm sejmik in the entry of his diary from August 19-20, 1748, the Vilnius coadjutor Józef Stanisław Sapieha mentions a palace in which the meeting of the tribunal sejmik was held ${ }^{24}$. And thus, also in 1748 the sejmik most likely gathered in the Palace of the Supreme Tribunal of GDL. What is more, in the economic inventory of Vilnius of 1762, it is stated that the Vilnius cathedral was located in front of a two-story building ("court castle"), in which the sessions of the Supreme Tribunal of GDL as well as the municipal and land courts ${ }^{25}$ were held. From these fragments of information, it can be deduced that the same building accommodated the sessions of the Supreme Tribunal of GDL, of the Vilnius municipal court, of the Vilnius land court, and presumably of the sejmik. Considering that in the exceptional circumstances (fires, etc.) the sejmik could not be hosted in the Castle Gate, it is quite probable that the meeting might have been taking place in the building of the Supreme Tribunal.

In 1737 the palace of the municipal and land court of the Vilnius voivodship was consumed by the fire. Even though the conflagration also damaged the Bishops' Palace, the Vilnius College, the St John's church and many other buildings, it was in the court palace that the fire started ${ }^{26}$. A similar fire broke out in $1748^{27}$. Nonetheless, the same year, the court palace was rebuild on the Vilnius voivode's initiative and the pre-Sejm sejmik was held there ${ }^{28}$.

At times, the sejmiks-in-exile of Smolensk and Starodub were hosted in the Palace of the Supreme Court of GDL. In 1741, the Starodub tribunal sejmik was held in the said palace, yet the press

${ }^{23} Z$ Wilna d. 28 Aug., "Kuryer Polski” 1740, No. 226.

24 "...in the chamber destined for the sejmik meetings and elections to the Tribunal...”. See Diary of Józef Stanisław Sapieha, The National Library of Poland in Warsaw, The Library of the Zamoyski Family Entail, 941, p. 491.

25 "....in front of the Cathedral, a two-story court castle destined for the Tribunal, land and municipal courts...". See The economic inventory of Vilnius of 1762 , LVIA, f. 21, op. 1, No. 125, p. 1. See M. Jučas, Rašytinès žinios, [in:] Lietuvos pilys, Vilnius 1971, p. 33.

${ }^{26} Z$ Grodna d. 5 Junii, "Kuryer Polski" 1737, No. 23.

27 A report on damages caused by the fire in 1748, The Scientific Library of PAU and PAN in Cracow, 1115, p. 5.

28 “...on last Tuesday, the gathering in the Court Chamber which was recently renovated on the expense of the Vilnius voivode..." See $Z$ Wilna $d: 24$ Aug, "Kuryer Polski" 1748, No. 615, p. 541v. 
of the period emphasizes that it was a non-standard place of the sejmik meeting (non in solito loco) ${ }^{29}$. It is worth mentioning that after the decision in the second half of the $17^{\text {th }}$ century to transfer the sejmik of the Smolensk voivodship to Vilnius, in 1691 the assembly was allowed to meet on the Lower Castle in Vilnius, which was located between the cathedral and the arsenal, opposite the old monetary $\operatorname{mint}^{30}$. Nevertheless, at the beginning of the $18^{\text {th }}$ century, the sejmiks-in-exile were held in the Bernardine monastery (the Smolensk sejmik) or in the chapel of the Church of St Francis and St Bernard (the Starodub sejmik). In 1764, the Starodub sejmik was moved to the Church of St Theresa (of the Discalced Carmelites) at the Gate of Dawn and it was there that the sessions took place until 1777. The sejmik of Starodub was later moved to Žiežmariai, and of Smolensk - to Alytus ${ }^{31}$.

In the $18^{\text {th }}$ century, hosting the three sejmiks in the Lower Castle became quite troublesome; hence, only the Vilnius sejmik remained at the location - as the most prestigious one.

Even when the assembly of the Vilnius sejmik was held in the Palace of the Supreme Tribunal of GDL, it is unlikely that it happened in the courtroom of the Tribunal since during the Vilnius term of office (April-September) the pre-Sejm sejmiks were most frequently taking place there. However, it can be assumed that the adjacent and connected buildings, the Palace of the Supreme Tribunal of GDL and the Castle Gate (Fig. 1), were often treated as one in the sources. For example, some entries in the records of the Vilnius municipal court make a reference to the gate by the Palace of

29 "...first the sejmik of Starodub non in solito loco, but in the tribunal court chamber..." See $Z$ Wilna d. 12. Febr., "Kuryer Polski" 1741, No. 220. It may imply that the Vilnius sejmik was held in the same place but a bit later.

${ }^{30}$ The privilege granted on June 21, 1691 to the sejmiks of the Smolensk voivodship and the Starodub county, allowing them to debate in the Vilnius castle. See Vilniaus Žemutiné pilis XIV a. - XIX a. pradžioje..., p. 266; L. G1e mža, Vilniaus Žemutinès pilies ansamblio topografija istoriniuose šaltiniuose, [in:] ibidem, p. 246; A. Ragauskas, op. cit., pp. 103-104.

${ }^{31}$ Urzędnicy Wielkiego Księstwa Litewskiego. Spisy, vol. IV (Ziemia smoleñska i województwo smoleńskie XIV-XVIII wiek), ed. A. Rachuba, Warszawa 2003, pp. 17-21; idem, Miejsca obrad sejmików..., pp. 190-191; R. Šmigelskytè-S tu ki e n è, Lietuvos Didžiosios Kunigaikštystès naujuju pavietu seimeliu vietos parinkimo ir ịrengimo problema 1792-1794 metais, Lietuvos Didžiosios Kunigaikštystès istorijos atodangos, profesoriaus Mečislovo Jučo 90-mečio jubiliejui skirtas moksliniu straipsniu rinkinys, sudarytojai V. Dolinskas, R. Petrauskas, E. Rimša, Vilnius 2016, p. 536. 


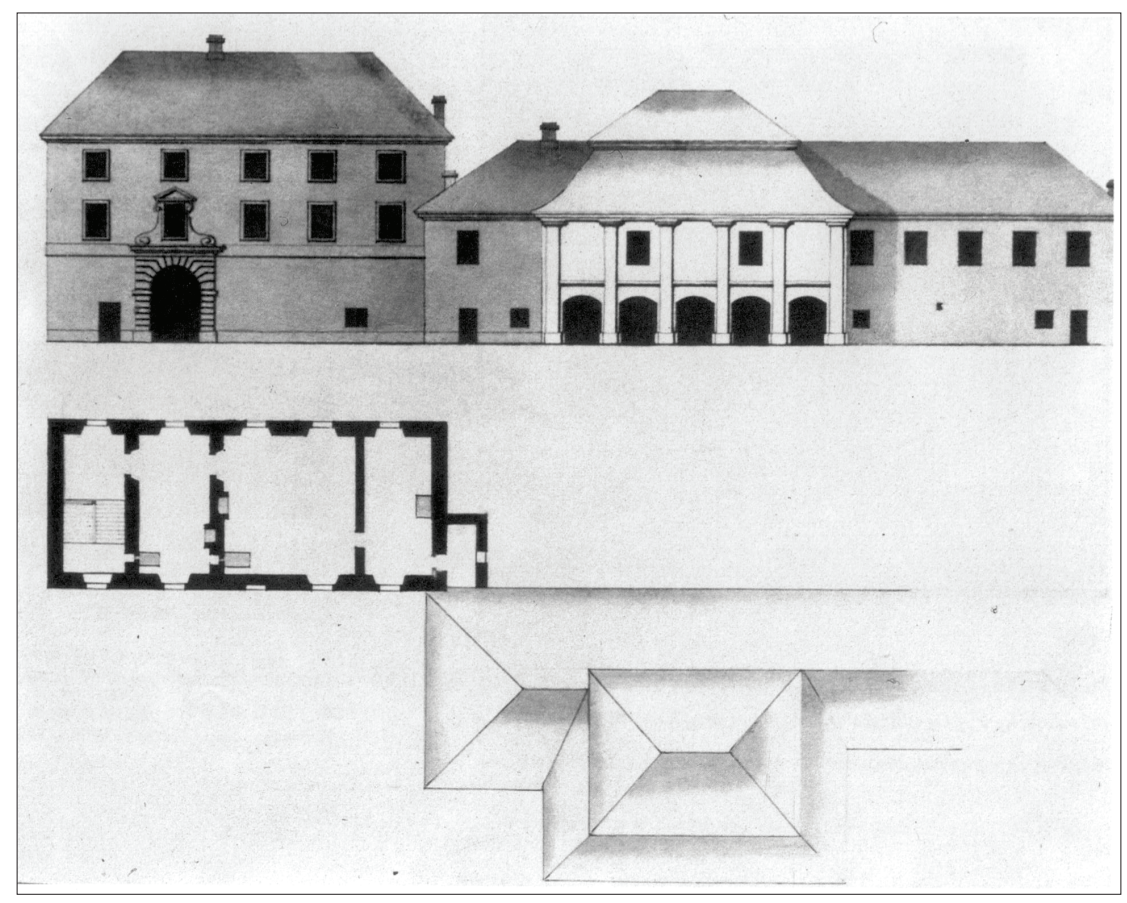

1. The Castle Gate and the Palace of the Supreme Tribunal of the Grand Duchy of Lithuania in Vilnius. K. Szildhauz. Sketch from 1820

(V. Drè ma, Dingęs Vilnius, Vilnius 2013, p. 141)

the Supreme Tribunal of GDL ${ }^{32}$. These issues require more in-depth research but what indicates that the meeting place of the Vilnius sejmik as well as the Vilnius municipal and land court might have been changing is the resolution of the economic sejmik of February 8,1785 , which states that different locations of the Vilnius municipal and land courts are not convenient for the arriving nobility. A special tax was introduced in order to collect a necessary sum of money for the construction of a new court building in the Vilnius county ${ }^{33}$. The construction of a new court palace began in $1786^{34}$.

32 "...to the gate of the palace when the sitting of the Supreme Tribunal of GDL takes place..." See LVIA, f. 21 , op. 1, No. 70, p. 493, 563v.

33 "...destruction of walls of the Vilnius Castle that was the meeting place for the land and municipal courts of our voivodship which so far did not have their own separate locations..." See The resolution of the Vilnius sejmik of February 8, 1785, LVIA, f. 21, op. 1, No. 142, pp. 91-92v.

${ }^{34}$ The historiography wrongly claims that the palace was built already in 1786 . See R. J an on ie nè, XVI-XIX a. Vilniaus Žemutinés pilies ikonografiniai šaltiniai, 


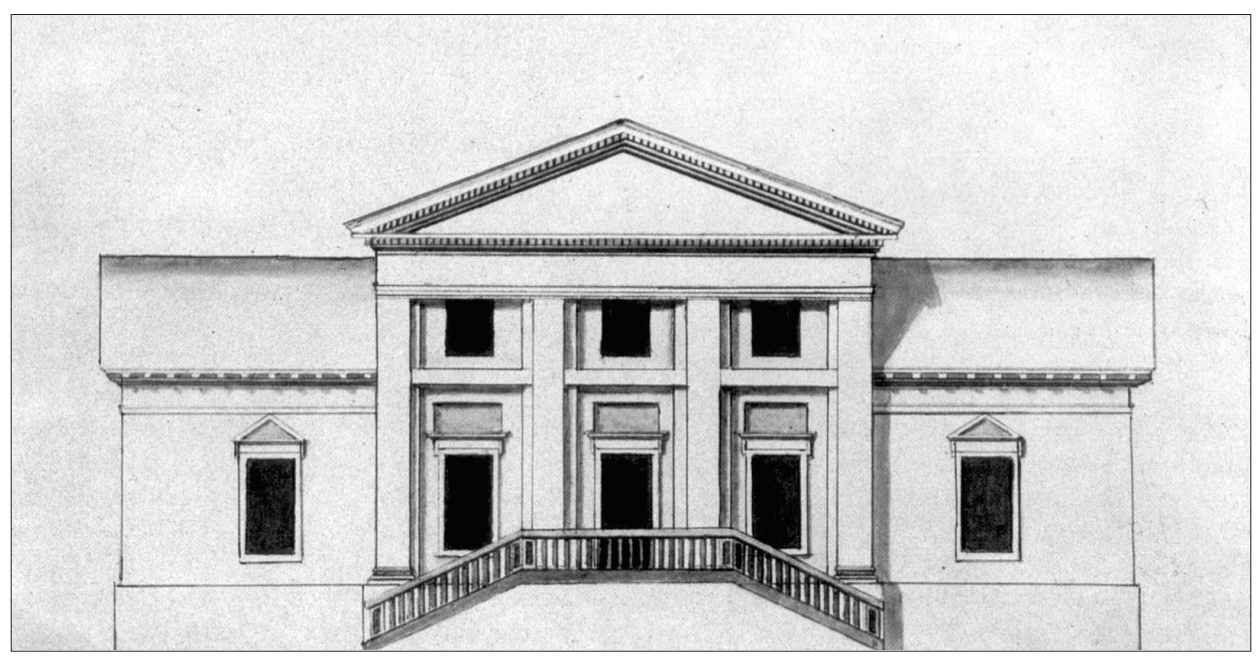

2. The newly erected palace of the municipal court and the land court of Vilnius. Sketch from 1786 (V. D rèm a, Dingęs Vilnius, Vilnius 2013, p. 144)

In the last years of the existence of GDL, the nobility of Vilnius county could, therefore, gather in the newly built palace of the municipal court and land court of Vilnius (Fig. 2), located near the Vilnius Cathedral. Thus far, the date of its erection has not been established. Ryszard Mienicki observes that the construction of a new Vilnius castle palace and a land court began in 1786, though it was not until 1802 that it held first court sessions. In the historiography of recent years, opinions are mixed regarding the date of its construction and its purpose ${ }^{35}$. The latest comprehensive study of the territory of Vilnius castles, especially the analysis of the Vilnius city plan which was created by Karol Grunart in $1808^{36}$ and which reflects the situation of 1790 and the numbering of properties at that time ${ }^{37}$, indicates that the new palace of the municipal and land courts was situated on the property No. 463. More detailed information about the planned structure of the building is provided

[in:] Vilniaus Žemutinè pilis XIV a. - XIX a. pradžioje: 2002-2004 m. istorinių..., pp. $21,23$.

${ }^{35}$ More information on the issue, see R. Jurgait is, Ar XVIII a. pabaigoje buvo pastatyti Lietuvos Metrikos archyvo rūmai Vilniuje?, "Lietuvos Metrikos naujienos" 2006, No. 8, pp. 51-55.

${ }^{36}$ The copy of K. Grunart's Vilnius city plan from 1808. See Vilniaus Žemutine pilis XIV a. - XIX a. pradžioje: 2002-2004 m. istoriniu šaltiniu paieškos, Vilnius 2006, p. 252.

${ }^{37}$ L. Glemža, op. cit., pp. 253-254. 
in the ordinance of the tsarist administration of January 27, 1832. Before the building was demolished, its structure was strengthened. At the beginning of the $19^{\text {th }}$ century, the second department of the Supreme Court of the Vilna Governorate started operating in the said building; on the second floor, there were five rooms, an anteroom, a hall and a courtroom of 30 arshines $^{38}$. It was in that spacious room that the nobility of the Vilnius voivodship could debate during the sejmik sessions at the end of the $18^{\text {th }}$ century. The studies from recent years demonstrate that the building could have been put up already in 1794. It is confirmed by the report of December 28, 1797, drawn up by its architect Marcin Knakfus, which was added to the records of the Vilnius municipal court on January $8,1798^{39}$. Thus, the session of the Vilnius sejmik could have been taking place in this building no sooner than in 1794, but none of the sources confirm such a claim. Once it was constructed, it had to be furnished and when the Kościuszko Uprising started (1794), unforeseen obstacles might have been encountered. On the other hand, since the building is called differently in various sources (new chancery ${ }^{40}$, archives of GDL $^{41}$ ), it could have been given a new intended purpose for functional reasons.

\section{Non in solito loco}

It is somewhat more difficult to establish the non-standard meeting place of the Vilnius sejmik. Yet, the research into its activities that was conducted in the recent years allowed to locate a few of them. The sessions of the Vilnius sejmik could have been taking place in the Cathedral of St Stanislaus and St Ladislaus in Vilnius. In 1737 , the opposition group of the tribunal sejmik had debates

38 [Estate] No. 463. The nobility owned a two-story brick house. See Vilniaus Žemutine pilis XIV a. - XIX a. pradžioje..., p. 299.

${ }^{39}$ LVIA, f. 20, op. 1, No. 48, p. 30v; Vilniaus Žemutinè pilis XIV a. - XIX a. pradžioje: 2002-2004 m. istoriniu šaltiniu paieškos..., pp. 268-269.

40 "Kancelarya nowa". See Schema to a description of the spaciousness of the city of Vilnius, LVIA, f. 458, op. 1, No. 317, pp. 15v-16.

41 "The Archives of GDL in the so-called old castle in Vilnius". See LVIA, f. 20, op. 1, No. 48, p. 30v. "in the archives in Vilnius". See LVIA, f. 20, op. 1, No. 344, p. 31 . The building could have been called the archive of GDL owing to an emerging opinion that the archives of most important GDL institutions should be stored in one place. See Deklaracya o sadach trybunalskich $w$ Wielkim Xięstwie Litewskim, VL, vol. IX, p. 419. 
in the Chapel of St Casimir ${ }^{42}$, though it is hard to assess whether the sejmik itself could have gathered there. The description of the sejmik of February 4-7, 1771, mentions the commencement of the session in the sejmik room ("in the sejmik chamber"), but the election of deputies to the Supreme Tribunal of GDL and of chamberlain took place in the Vilnius Cathedral ${ }^{43}$. There are more sources confirming that the sejmik of 1771 met in this specific church ${ }^{44}$. In addition, on February 4, 1760, the Vilnius tribunal sejmik was initially held in the cathedral as well ${ }^{45}$. The supporters of the Abramowicz family gathered there ${ }^{46}$ and the Castellan of Brest, Andrzej Abramowicz, opened the session as the person highest in rank.

It can be assumed that while it was customary for the sejmiks of GDL to gather in churches, the nobility of the Vilnius voivodship did so only by way of exception. Initially, sacral buildings were chosen for practical reasons, they were spacious and could accommodate a large amount of participants. Apart from that, before the sejmik began, there was a mass celebrated in the Vilnius Cathedral, which means it was convenient to hold the sejmik sessions there as well. In some circumstances, the Vilnius Cathedral was a setting for the activity of the Supreme Tribunal of GDL, where it held its opening, where the powers of deputies went under control and the oaths were taken. At least that was the plan of its opening in the years $1756-1763^{47}$ and possibly it happened more frequently.

42 The manifesto of the nobility from the Vilnius voivodship of February 4, 1737, The National Library of Russia in St. Petersburg, The collection of P.P. Dubrowski's manuscripts, No. 150, p. 38.

43 "...or in the Vilnius Cathedral church where the election of HM deputies and the chamberlain took place". See The description of the Vilnius sejmik of 1777 , AGAD, ZP 722, pp. 466-467v.

44 "....in the sejmik chamber or in the church, where Esqs. deputies were elected..." See The complaint of Antoni Sejbut Romanowicz filed against Tadeusz Żaba on February 8, 1771, LVIA, f. 21, op. 1, No. 130, p. 29.

45 "...you gathered in the Cathedral church located in the Castle, where after opening the session by Esq. Chamberlain Horain and electing Esq. son of the cupbearer Zaleski for the director". See A notification from Vilnius, February 4, 1760, AGAD, AR, sec. XXXIV, 496, p. 1. A notification from Vilnius of February 4, 1760 r., Vilniaus Žemutiné pilis XIV a. - XIX a. pradžioje..., p. 344.

${ }^{46}$ The manifesto of the nobility of the Vilnius voivodship, February 4, 1760, LVIA, f. 21, op. 1, No. 117, pp. 52-52v; The manifesto of Jan Antoni Horain, February 5,1760 , ibidem, pp. 58-59v.

47 "...Apart from that, from the Flemingowski tribunal of 1756, the deputies' oaths were listened to in the aforementioned church..." "...After this ceremony 
Yet, the sejmik sessions in the second half of the $18^{\text {th }}$ century were rarely held in the aforesaid cathedral. First, in 1752-1754 the Vilnius Cathedral was being renovated ${ }^{48}$. On September 2, 1769 , one of its towers got destroyed by the storm and killed several priests while collapsing. In 1778, the bishop ordered to close down the cathedral as it was in a critical state ${ }^{49}$. When the works of its reconstruction began in 1782 and were halted ${ }^{50}$, the service was held in the St John's Church ${ }^{51}$. It is, however, unknown if the sejmik sessions of the Vilnius voivodship were also taking place there ${ }^{52}$. Most likely, at the end of the $18^{\text {th }}$ century the masses that were an introduction to the work of sejmik were held in the said church as it performed all the functions of the Vilnius Cathedral while it was being reconstructed (1783-1801). Importantly, in 1786 the Bishop of Vilnius, Ignacy Massalski, forbid to organize sejmiks in the churches and monasteries of the Vilnius Diocese, threatening with an interdict ${ }^{53}$.

One more non-standard location of the Vilnius sejmik is mentioned in the sources. In 1776 , on July 16, i.e. on the second day of the pre-Sejm sejmik, the nobility gathered in the square at the Vilnius Cathedral, in the open air ${ }^{54}$. Even though the assembly was not exceptionally numerous, the size of the group was being

of establishing the tribunal, the Czartoryski party gathering again in the Vilnius cathedral church..." See M. M a tu s zewi cz, Diariusz życia mego, ed. B. Królikowski, comm. Z. Zielińska, vol. II, Warszawa 1986, p. 297, 298. “...in the Cathedral Church...", “...[in that church deportations were taking place..." See A notification from Vilnius, April 21, 1760, AGAD, AR, sec. XXXIV, 496, pp. 3-4; Diary of Michał Kazimierz Radziwiłł, alias Rybeńko, AGAD, AR, II-80a, pp. 2046-2048. According to Władysław Konopczyński's data, in 1761 deputies also swore in the Vilnius cathedral. See W. Kon o pczyńs ki, Od Sobieskiego do Kościuszki, Kraków 1921, p. 184.

${ }^{48}$ V. Drèm a, Dingęs Vilnius, Vilnius 2013, p. 115.

49 Id e m, Vilniaus Šv. Onos bažnyčia. Vilniaus katedros rekonstrukcija 17821801 metais, Vilnius 1991, p. 190.

50 Ibidem, pp. 195-198.

${ }^{51}$ V. D rèma, Šv. Jono bažnyčia, Vilnius 1997, p. 177.

52 The St. John's Church was located outside the Vilnius castles' territory. Thus, if sessions of the Vilnius sejmik were held there, it would have been stated very clearly in the sejmik documents.

${ }^{53}$ T. Ka sa bula, Ignacy Massalski biskup wileński, Lublin 1998, pp. 243-244; A.B. Zakrzewski, op. cit., p. 32.

54 “...the postponed session on the $16^{\text {th. }}$ The day in which the whole voivodship gathered in the square of the castle again..." See A description of the pre-Sejm sejmik of Vilnius of July 15-16, 1776, LVIA, f. 1135, op. 4, No. 33, pp. 645-646. 


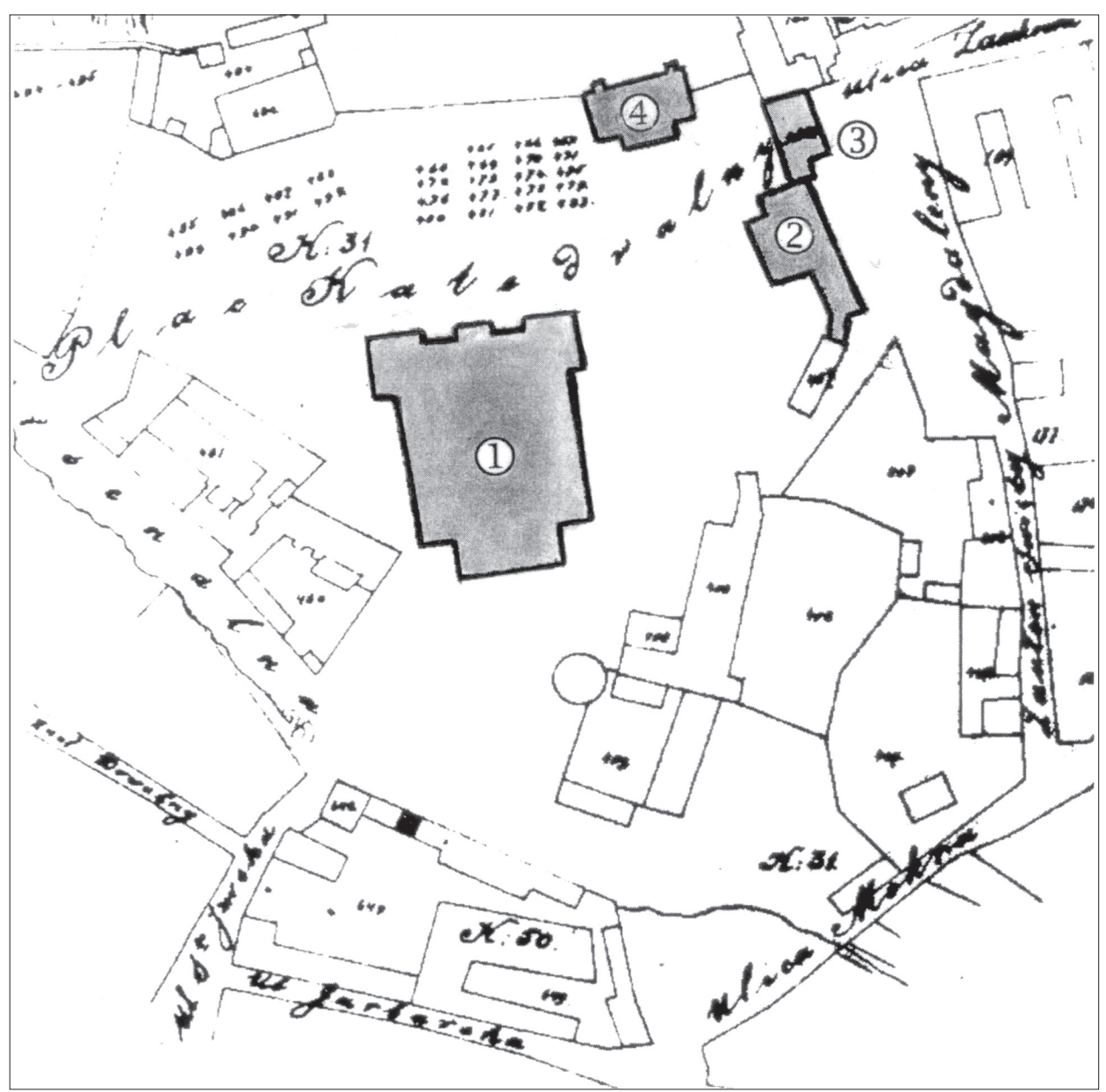

3. The view of the square at the Vilnius Cathedral in 1808. On K. Grunart's Vilnius city plan: 1 - the Vilnius Cathedral; 2 - the Palace of the Supreme Tribunal of GDL; 3 - the Castle Gate; 4 - the new building of the municipal and land court (new chancery)

restricted. The soldiers of the Russian army had a list of unwanted people and did not allow some noblemen to participate in the pre-Sejm sejmik (July 15, 1776). Not only sejmiks of Vilnius but also of Smolensk and of Starodub were controlled in a similar manner ${ }^{55}$. Over a thousand nobles gathered for the pre-Sejm Vilnius sejmik ${ }^{56}$

${ }^{55}$ V. Dolinskas, Simonas Kosakovskis: politine ir kariné veikla Lietuvos Didžiojoje Kunigaikštystèje 1763-1794, Vilnius 2003, p. 400.

56 "...a thousand and a few..." See A description of the pre-Sejm sejmik of Vilnius of July 15-16, 1776, LVIA, f. 1135, op. 4, No. 33, pp. 645-646. 
and it can be suspected that on July 16, they met in the open air in order to prevent the interference of the Russian army and make it difficult to control the activity of the sejmik. The location is by no means exceptional as the historiography mentions other instances of open-air sessions of the GDL sejmiks ${ }^{57}$.

\section{Conclusions}

Summing up, it can be said that in the $18^{\text {th }}$ century the Vilnius sejmik was held in Vilnius, and its standard locations were the Castle Gate and the Palace of the Supreme Tribunal of GDL. It was also possible to establish a few non-standard locations of its sessions, i.e.: the Cathedral of Stanislaus and St Ladislaus of Vilnius (in 1760 and 1771) as well as the square in front of it (in 1776). These were, however, exceptions that occurred after the formation of opposition groups or after the dissolution of the sejmik. Nonetheless, all these places were situated on the premises of the Lower Castle in Vilnius (Fig. 3).

\section{Bibliography}

\section{HANDWRITING SOURCES}

The Central Archives of Historical Records in Warsaw (Archiwum Główne Akt Dawnych w Warszawie) [AGAD]

The Public Archives of Potocki's Family 252.

(Archiwum Publiczne Potockich)

The Archives of the Radziwiłł Family

(Archiwum Radziwiłłów) [AR]

sec. VI, II-80a, Diary of Michał Kazimierz Radziwiłł, alias Rybeńko

(Dziennik Michała Kazimierza Radziwiłła zw. Rybeńko);

sec. XXXIV, 496.

The Popiele Collection 722.

(Zbiór Popielów) [ZP]

The Archives of the Zamoyski Family 3055.

(Archiwum Zamoyskich) [AZ]

${ }^{57}$ A.B. Zakrzewski, op. cit., p. 30. 
The National Library in Warsaw

(Biblioteka Narodowa w Warszawie)

The Library of the Zamoyski Family Entail 941.

(Biblioteka Ordynacji Zamojskiej)

Diary of Józef Stanisław Sapieha

(Dziennik Józefa Stanisława Sapiehy)

The Scientific Library of PAU and PAN in Cracow 1115

(Biblioteka PAU i PAN w Krakowie)

A report on damages caused by the fire in 1748 .

(Relacja o szkodach, które uczynił pożar w 1748 r.)

The Vrublevskiai Library of the Lithuanian Academy of Sciences in Vilnus (Biblioteka Litewskiej Akademii Nauk im. Wróblewskich)

f. 139 , nr 1197.

The Lithuanian State Historical Archives in Vilnius

(Litewskie Państwowe Archiwum Historyczne w Wilnie) [LVIA]

f. 20 , op. 1 , nr $39 ; 48 ; 187 ; 344$;

f. 21 , op. 1 , nr $67 ; 70 ; 71 ; 91 ; 103 ; 117 ; 121 ; 125 ; 128 ; 130 ; 139$;

f. 458 , op. 1 , nr 317 ;

f. 1135 , op. 4 , nr 33 .

The National Library of Russia in St. Petersburg

(Rosyjska Biblioteka Narodowa w Sankt Petersburgu)

The collection of P.P. Dubrowski's manuscripts, No. 150.

(Kolekcja autografów P.P. Dubrowskiego)

\section{Printed sources}

Akty izdavaiemyje Vilenskoju archeograficzeskoju komisieju dla razbora drievnich aktov, vol. XIII.

Dyaryusz Seymu convocationis Siedmio-Niedzielnego Warszawskiego zdania, Mowy, Projekta y Manifesta $w$ sobie zawieraiacy, przez Sesye zebrany R.P. 1764 w warszawie, [1764].

Matuszewicz M., Diariusz życia mego, ed. B. Królikowski, comm. Z. Zielińska, vol. II, Warszawa 1986.

Volumina legum, vol. IX, Kraków 1889; vol. X, Poznań 1952.

Wilenskie Woiewodztwo, Kalendarz polityczny na Rok P. 1747, Lublin [1747]. 


\section{Press}

“Gazeta Narodowa Wileńska” 1794, No. 2.

"Kuryer Polski" 1737, No. 23.

"Kuryer Polski” 1740, No. 163; No. 226.

"Kuryer Polski" 1741, No. 220.

“Kuryer Polski” 1742, No. 272.

“Kuryer Polski” 1748, No. 615.

\section{STUdies}

Dolinskas V., Simonas Kosakovskis: politinè ir kariné veikla Lietuvos Didžiojoje Kunigaikštystèje 1763-1794, Vilnius 2003.

Drèma V., Dingęs Vilnius, Vilnius 2013.

Drèma V., Šv. Jono bažnyčia, Vilnius 1997.

Drèma V., Vilniaus Šv. Onos bažnyčia. Vilniaus katedros rekonstrukcija 1782-1801 metais, Vilnius 1991.

Glemža L., Vilniaus Žemutinès pilies ansamblio topografija istoriniuose šaltiniuose, [in:] Vilniaus Žemutiné pilis XIV a. - XIX a. pradžioje: 2005-2006 m. tyrimai, sudarè L. Glemža, Vilnius 2007, pp. 243-255.

Janonienè R., XVI-XIX a. Vilniaus Žemutinès pilies ikonografiniai šaltiniai, [in:] Vilniaus Žemutine pilis XIV a. - XIX a. pradžioje: 2002-2004 m. istoriniu šaltiniu paieškos, sudarė R. Ragauskienė, Vilnius 2006, pp. 11-43.

Jučas M., Rašytinès žinios, [in:] Lietuvos pilys, Vilnius 1971, pp. 25-34.

Jurgaitis R., Ar XVIII a. pabaigoje buvo pastatyti Lietuvos Metrikos archyvo rūmai Vilniuje?, "Lietuvos Metrikos naujienos" 2006, Nr. 8, pp. 51-55.

Jurgaitis R., Bajoriškas seimelis mieste: kur vykdavo Vilniaus seimelio posédžiai 1717-1795 m.?, [in:] Lietuvos Didžioji Kunigaikštystè XVIII amžiuje: miesto erdvé, Vilnius 2007, pp. 45-53.

Kasabula T., Ignacy Massalski biskup wileński, Lublin 1998.

Konopczyński W., Od Sobieskiego do Kościuszki, Kraków 1921.

Kriegseisen W., Sejmiki Rzeczypospolitej szlacheckiej w XVII i XVIII wieku, Warszawa 1991.

Rachuba A., Miejsca obrad sejmików Wielkiego Księstwa Litewskiego w latach 1569-1794, [in:] Parlamenckije struktury ulady u sistemie dzerzavnaga kiravanie Velikaga Kniastva Litouskaga, Minsk 2008, pp. 183-197.

Rachuba A., Wielkie Ksiestwo Litewskie w systemie parlamentarnym Rzeczypospolitej w latach 1569-1763, Warszawa 2002.

Ragauskas A., Viešasis gyvenimas Vilniaus Žemutinès pilies teritorijoje XVIII a., [in:] Vilniaus Žemutiné pilis XIV a. - XIX a. pradžioje: 2005-2006 m. tyrimai, sudarè L. Glemža, Vilnius 2007, pp. 100-110.

Seredyka J., Instrukcje powiatu wileńskiego na sejmy za panowania Zygmunta III Wazy, "Śląski Kwartalnik Historyczny Sobótka" 1993, vol. XLVIII, No. 2-3, pp. 189-197. 
Šmigelskytė-Stukienė R., Lietuvos Didžiosios Kunigaikštystės naujuju pavietu seimeliu vietos parinkimo ir irengimo problema 1792-1794 metais, Lietuvos Didžiosios Kunigaikštystès istorijos atodangos, profesoriaus Mečislovo Jučo 90-mečio jubiliejui skirtas moksliniu straipsniu rinkinys, sudarytojai V. Dolinskas, R. Petrauskas, E. Rimša, Vilnius 2016, pp. 529-544.

Szwaciński T., Sejmiki poselskie przed konwokacja 1764 r., "Kwartalnik Historyczny" 2006, vol. CXIII, No. 1, pp. 19-56.

Urzędnicy Wielkiego Księstwa Litewskiego. Spisy, vol. IV (Ziemia smoleńska i województwo smoleńskie XIV-XVIII wiek), ed. A. Rachuba, Warszawa 2003.

Vilniaus Žemutinè pilis XIV a. - XIX a. pradžioje: 2002-2004 m. istoriniu šaltiniu paieškos, sudarè Raimonda Ragauskienè, Vilnius 2006.

Zakrzewski A.B., Sejmiki Wielkiego Księstwa Litewskiego XVI-XVIII w. Ustrój i funkcjonowanie: sejmik trocki, Warszawa 2000. 